\title{
PENGARUH MODEL INKUIRI BEBAS TERHADAP KEMAMPUAN LITERASI SAINS
}

\section{THE INFLUENCE OF FREE INQUIRY MODEL ON SCIENCE LITERACY SKILLS}

\author{
Siti Aisyah Siska Haerani, Dadi Setiadi, dan Dewa Ayu Citra Rasmi \\ Program Studi Pendidikan Biologi FKIP Universitas Mataram, Mataram, Indonesia \\ Email: sitiaisyahhaerani23@gmail.com
}

Diterima: 5 Februari 2020. Disetujui: 7 Februari 2020. Dipublikasikan: 2 Maret 2020

\begin{abstract}
Abstrak: Literasi sains penting dikembangkan bagi peserta didik agar mereka memiliki kemampuan dalam menjelaskan fenomena secara ilmiah, mengevaluasi desain penyelidikan ilmiah dan menginterpretasi dan membuktikan data secara ilmiah. Salah satu model yang bisa mendukung pencapaian kompetensi tersebut adalah pembelajaran Inkuiri Bebas. Tujuan penelitian ini adalah untuk mengetahui pengaruh model inkuiri bebas terhadap kemampuan literasi sains siswa kelas XI SMAN 2 Labuapi. Jenis penelitian yang digunakan adalah eksperimen semu (Quasi Experiment), dengan desain nonequivalent pretest-posttest kontrol group desain. Populasi penelitian adalah seluruh siswa kelas XI MIPA (37 orang), tekhnik pengambilan sampel dengan cara sampling total. Data dianalisis dengan menggunakan MANOVA). Hasil penelitian menunjukan bahwa model inkuiri bebas berpengaruh signifikan terhadap kemampuan literasi sains peserta $\operatorname{didik}(p=0,002<0,05)$, sehingga dapat disimpulkan bahwa model inkuiri bebas bisa digunaka untuk meningkatkan kompetensi literasi sains siswa kelas XI SMAN 2 Labuapi.
\end{abstract}

Kata Kunci: Model Inkuiri Bebas, Kemampuan Literasi Sains

\begin{abstract}
Science literacy skills are important to be developed for students so they have the ability to explain phenomena scientifically, evaluate the design scientific inquiry and interpret evidence and data scientifically. One of model that can be support achieving these competencies is Free Inquiry Model. The research aimed is to know the influence of the free inquiry model to the science literacy skills of grade XI state senior high school 2 Labuapi. This type of research used was Quasi-Experiment, with a Non-Equivalent Pretest-Posttest Control Group Design. The study population was all students of grade XI (37 studens), the sampling technique was total sampling. Data were analyzed using MANOVA. The results show that the free inquiry model influences significant effect on the science literacy skills of students ( $\mathrm{p}=0.002<0.05)$, so it can be concluded that the free inquiry model could be used to improve the science literacy competencies of grade XI state senior high school 2 Labuapi.
\end{abstract}

Keywords: Learning Model, Free-inquiry Model, Science Literacy

\section{PENDAHULUAN}

Permasalahan yang dihadapi dalam dunia pendidikan saat ini adalah kemampuan literasi sains siswa Indonesia yang sangat rendah, hal ini menjadi salah satu masalah yang harus segera di atasi [1]. Berdasarkan hasil pemetaan peringkat Indonesia di PISA pada tahun 2009 yaitu ke-57 dari 65 dengan perolehan skor 383. Pada tahun 2012 Indonesia menduduki peringkat ke-64 dari total 65 negara dengan perolehan nilai yaitu 382 . Selanjutnya, pada tahun 2015 Indonesia berada pada peringkat ke-64 dari 72 negara yang ikut serta, dengan perolehan skor yaitu 403 [2]. Pencapaian prestasi IPA berdasarkan survei Trends in Mathematics and Science Study (TIMSS) oleh The International Association for the Evaluation of Educational Achievement (IEA) tahun 2015 posisi Indonesia menempati peringkat ke-44 dari 47 negara dengan nilai rata-rata 397. Kemampuan literasi sains peserta didik Indonesia masih tergolong rendah dan berada di bawah rata-rata skor Internasional.

Literasi sains didefinisikan sebagai kemampuan menggunakan pengetahuan sains, mengidentifikasi permasalahan, menarik kesimpulan berdasarkan bukti-bukti, dan akhirnya membuat sebuah keputusan yang tepat [3] (Organization for Economic Cooperation and Development, 2016). Literasi sains merupakan kemampuan yang digunakan untuk menginterpretasikan sains, yang mampu memberikan peluang sebagai solusi terhadap permasalahan yang dihadapi dalam kehidupan sehari-hari [4]. Pentingnya kemampuan literasi sains perlu dipersiapkan pada peserta didik berfungsi untuk menyelesaikan permasalahan dalam kehidupan sehari-hari. Setiap individu perlu menguasai kemampuan literasi sains, hal ini berkaitan dengan bagaimana seseorang dapat memahami permasalahan dilingkuan hidup dan masalah-masalah lain yang dihadapi oleh masyarakat modern yang sangat bergantung pada ilmu pengetahuan dan tekhnologi [5]. Skor peserta didik Indonesia berada pada tingkat 1 dari maksimal 5, sedangkan pencapaian tingkat 1 hanya berotientasi pada kemampuan yang paling rendah dan menunjukan bahwa pembelajaran hanya berotientasi pada kemampuan menghafal dan mengingat fakta-fakta sederhana, sedangkan tagihan 
pembelajaran kurikulum 2013 mengarahkan pada peningkatan kemampuan literasi sains [6].

Upaya peningkatan kemampuan literasi peserta didik dapat dilakukan melalui pembelajaran yang menekankan pada kemampuan literasi sains [1]. Selain itu membangun kemampuan literasi siswa dapat dilakukan dengan pembelajaran yang semuanya berpusat pada peserta didik, sehingga melatih peserta didik untuk menggunakan pengetahuan ilmiah, mengidentifikasi pertanyaan dan menarik kesimpulan berdasarkan fakta. Pertanyaan-pertanyaan yang sering diajukan hanya pertanyaan yang menekan pada kemampuan mengingat pengetahuan, fakta-fakta, kemampuan mengaplikasi pengetahuan yang diperoleh tidak dibiasakan akibatnya kemampuan berpikir tingkat tinggi siswa kurang berkembang [6].

Model pembelajaran inkuiri merupakan salah satu inovasi pembelajaran yang dapat memperoleh pengetahuan lebih dalam [7]. Penggunaan model inkuiri lebih melibatkan peserta didik dalam proses pembelajaran, karena secara langsung ikut aktif dan mengambil peran lebih besar selama kegiatan pembelajaran, baik pengamatan, eksperimen, maupun kegiatan investigasi [8]. Model inkuiri yang menekan siswa mencari tahu dan lebih mandiri salah satunya adalah inkuiri bebas. Inkuiri bebas menekankan peserta didik bekerja sendiri baik dari merumuskan masalah hingga menemukan jawaban dari masalah tersebut, sehingga kemandirian peserta didik sangat diperhatikan dalam kegiatan pembelajarannya [9].

Model pembelajaran inkuiri bebas baik digunakan untuk melatih kemampuan berpikir tingkat tinggi peserta didik berdasarkan hasil pengamatan yang menunjukan bahwa model pembelajaran inkuiri terbimbing (guided inquiry) dan inkuiri bebas (free inquiry) secara positif baik digunakan untuk melatih kemampuan berpikir tingkat tinggi [10]. Proses pembelajaran inkuiri melibatkan kemampuan peserta didik secara maksimal untuk mencari dan menyelidiki secara sistematis, kritis, logis, analitis.

\section{METODE PENELIATIAN}

Jenis penelitian yang digunakan adalah eksperimen semu (Quasi Experiment), dan desain nonequivalent pretest-posttest kontrol group design. Dengan adanya pretest dalam desain penelitian maka dapat digunakan untuk pengontrolan secara statistik dan dapat melihat pengaruh perlakuan model inkuiri bebas dan model pembelajaran langsung terhadap capaian skor. Kelompok eksperimen diberikan perlakuan model inkuiri bebas dan kelompok kontrol dengan model pembelajaran langsung. Populasi dalam penelitian ini adalah seluruh siswa kelas XI MIPA (37 orang) SMAN 2 Labuapi Tahun ajaran 2019/2020. Pemilihan sampel yang digunakan adalah tekhnik sampling total atau sensus tekhnik. Pengumpulan data kemampuan berpikir kritis dilakukan dengan menggunakan instrument tes, yaitu tes tipe pilihan ganda. Analisis data penelitian dilakukan melalui uji MANOVA dengan menggunakan SPSS 17.00.

\section{HASILDAN PEMBAHASAN}

Hasil analisis kemampuan literasi sains dengan menerapkan model inkuiri bebas dan model konvensional pada peserta didik kelas XI MIPA SMAN 2 Labuapi Tahun Ajaran 2019/2020. Ratarata hasil pre-test dan post-test kemampuan literasi sains peserta didik dapat divisualisasikan pada tabel 1.

Tabel 1: Hasil Pre-test dan Post-Test KemampuanLiterasi Sains

\begin{tabular}{lclllll}
\hline \multicolumn{5}{c}{ Descriptive Statistics } \\
\hline \multicolumn{1}{c}{ KLS } & N & Min & Max & Mean & SD \\
Pretes Kelompok & 18 & 5 & 50 & 20.83 & 10.182 \\
$\begin{array}{l}\text { Eksperimen } \\
\text { Posttest kelompok }\end{array}$ & 18 & 55 & 80 & 67.50 & 7.717 \\
$\begin{array}{l}\text { Eksperimen } \\
\text { Pretest Kelompok }\end{array}$ & 19 & 10 & 50 & 23.42 & 13.129 \\
$\begin{array}{l}\text { Kontrol } \\
\text { Posttest Kelompok }\end{array}$ & 19 & 40 & 85 & 56.32 & 12.230 \\
$\begin{array}{l}\text { Kontrol } \\
\text { Valid N (listwise) }\end{array}$ & 18 & & & & \\
\hline
\end{tabular}

Berdasarkan hasil pre-test dan post-test yang disajikan pada tabel 1 menunjukan hasil kemampuan literasi sains peserta didik kelompok eksperimen dan kelompok kontrol. Nilai pre-test tertinggi kelompok eksperimen adalah 50 dan nilai terendah adalah 5, sedangkan nilai pre-test tertinggi kelompok kontrol adalah 50 dan nilai terendah adalah 10. Nilai rata-rata yang ditunjukan pada tabel 1 menunjukan rata-rata pre-test kemampuan literasi sains pada kelompok eksperimen sebesar 20,83, sedangkan nilai rata-rata pre-test kelompok kontrol adalah 23,42. Hasil rata-rata post-test kelompok eksperimen sebesar 67,50 sedangkan kelompok kontrol sebesar 56,32. Berdasarkan hasil rata-rata pre-test maupun post-test menunjukan bahwa nilai pre-test kelompok kontrol lebih tinggi dibandingkan kelompok eksperimen sebesar 23,42, akan tetapi nilai rata-rata post-test kelompok eksperimen memiliki nilai lebih tinggi dibandingkan kelompok kontrol yaitu 67,50, sehingga dapat disimpulkan bahwa setelah diberikan perlakuan model pembelajaran inkuiri bebas terhadap kelompok eksperimen dan model pembelajaran konvensional pada kelompok kontrol menunjukan hasil yang tidak jauh berbeda pada hasil rata-rata nila kemampuan literasi sains tersebut, walaupun hasil post-test kelompok eksperimen memiliki nilai lebih tinggi.

Berdasarkan hasil analisis TestBetweenSubject Effect yang menunjukanadanya pengaruh 
variabel secara individu, untuk mengetahui pengaruh variabel bebas dan kovariat terhadap masing-masing variabel tergantung. Hasil uji output TestBetween-Subject Effect ditunjukan pada tabel 2.

Tabel 2: Hasil Test of Between-Subject Effect

\begin{tabular}{llrlrrr}
\hline \multicolumn{7}{c}{ Tests of Between-Subjects Effects } \\
\hline \multicolumn{7}{c}{ Type III } \\
Source & DV & Sum of & d & Mean & & \\
Correc & KL & 1156.20 & 1 & 1156.2 & 10.9 & .00 \\
ted & S & $6^{\mathrm{a}}$ & & 06 & 23 & 2 \\
Model & & & & & & \\
Interce & KL & 141702. & 1 & 141702 & 133 & .00 \\
pt & S & 151 & & .151 & 8.75 & 0 \\
& & & & & 9 & \\
Kelas & KL & 1156.20 & 1 & 1156.2 & 10.9 & .00 \\
& S & 6 & & 06 & 23 & 2 \\
Error & KL & 3704.60 & 3 & 105.84 & & \\
Total & S & 5 & 5 & 6 & & \\
& SL & 145975. & 3 & & & \\
Correc & KL & 4860.81 & 3 & & & \\
ted & S & 1 & 6 & & & \\
Total & & & & & & \\
\hline
\end{tabular}

Keterangan: *DV= Dependent Variabel *KLS= Kemampuan Literasi Sains

Hasil uji output TestBetween-Subject Effect menunjukan pada kolom variasi (source) baris kelas terlihat bahwa nilai $\mathrm{F}$ untuk memapuan literasi sains adalah 10,923 dengan nilai signifikan sebesar 0,002, berdasarkan nilai $p$-value (Sig) yang diperoleh nilai kemampuan literasi sains menunjukan nilai 0,002 < 0,05. Maka $H_{0}$ ditolak yang berbunyi "Tidak terdapat pengaruh model inkuiri bebas terhadap peningkatan kemampuan literasi sains siswa kelas XI SMAN 2 Labuapi tahun ajaran 2019/2020. Sehingga dapat disimpulkan bahwa $H_{a}$ yang menyatakan "Terdapat pengaruh model inkuiri bebas terhadap peningkatan kemampuan literasi sains siswa kelas XI SMAN 2 Labuapi tahun ajaran 2019/2020" diterima.

Berdasarkan hasil pengamatan Test Between Subject Effect menampilkan hasil pada (tabel 2) bahwa kemampuan literasi sains menunjukan (nilai $\mathrm{p}=<0,05)$ yaitu $(0,002<0,05)$, sehingga $H_{\circ}$ tidak di terima yang artinya bahwa $H_{a}$ diterima. Sehingga dapat disimpulkan bahwa model inkuiri bebas signifika terhadap kemampuan berpikir kritis. Pembelajaran inkuiri mampu meningkatkan keterampilan proses (mengamati, mengidentifikasi, membedakan, mengklarifikasi, menafsirkan, menggambarkan, mengkomunikasi, dan menyimpulkan) [11]. Berdasarkan hasil Test Between Subject Effect menunjukan bahwa penggunaan model pembelajaran inkuiri bebas memiliki pengaruh terhadap peningkatan kemampuan literasi sains siswa kelas XI SMAN 2
Labuapi. Dengan demikian model inkuiri bebas mampu membangun kemampuan literasi sains dengan memfasilitasi peserta didik dengan tahaptahap pembelajaran yang menjadi dasar dalam mencapai aspek kompetensi literasi sains yang terdiri dari menjelaskan fenomena secara ilmiah, mengevaluasi dan mendesain penyelidikan ilmiah, dan Interpretasi data dan membuktikan data secara ilmiah. Langkah pembelajaran orientasi dapat mengembangkan literasi sains aspek menjelaskan fenomena ilmiah, langkah menganalisis data dapat mengembangkan literasi sains indikator menginterpretasikan bukti dan data ilmiah, dan langkah pembelajaran menyusun kesimpulan dapat mengembangkan literasi sains indikator merancang dan mengevaluasi penyelidikan ilmiah [12]. Berdasarkan pernyataan tersebut maka model inkuiri bebas mampu mendukung pengembangan kemampuan literasi sains peserta didik, karena memiliki langkah pembelajaran yang menjadi dasar pencapaian tiga kompetensi literasi sains. Pembelajaran dengan inkuiri pada dasarnya adalah peserta didik belajar IPA melalui penyelidikan, yaitu penyelidikan terhadap fenomena atau masalah yang berkaitan dengan IPA untuk menemukan konsep atau prinsip IPA. Adapun komponen kompetensi literasi sains dapat dibagi menjadi tiga yaitu, menjelaskan fenomena secara ilmiah, Mengevaluasi dan mendesain penyelidikan Ilmiah, dan Interpretasi data dan membuktikan data secara ilmiah.

Indikator menjelaskan fenomena secara ilmiah yaitu kemampuan yang menuntut siswa selalu mengembangkan rasa ingin tahunyadalam menjawab segala pertanyaan yang diberikan dengan proyek yang telah dilaksanakan [13]. Dalam hal ini peserta didik diharapkan mampu mengaplikasikan pengetahuan yang dimilikinya dalam situasi yang diberikan untuk menjelaskan atau mendeskripsikan fenomena dan mendeskripsikan perubahan, mengidentifikasi deskripsi, eksplanasi dan prediksi yang sesuai. Kompetensi menjelaskan fenomena secara ilmiah dibutuhkan peserta didik untuk mengingat kembali konten pengetahuan yang tepat pada keadaan yang diberikan dan menggunakannya untuk menginterpretasi dan menyediakan penjelasan kepada fenomena yang menarik [3]. Langkah pembelajaran inkuiri bebas yang memenuhi kriteria pencapaian kompetensi ini terdapat pada fase berhadapan dengan masalah, mengumpulkan data pengujian, dan pengumpulan data dalam kegiatan pengamatan.

Tahap pembelajaran menjelaskan fenomena alam mengarahkan peserta didik dalam kegiatan merumuskan masalah secara individu maupun kelompok dan menentukan cara penyelesaian masalah, proses tersebut akan menuntut peserta didik untuk mengelolah pengetahuan yang dimilikinya dalam menyelesaikan masalahnya berdasarkan keadaan yang diberikan oleh pendidik, setelah itu peserta didik melakukan 
pengumpulan data dalam kegiatan pengujian, dengan kegiatan melakukan identifikasi terhadap kejadian atau fenomena dalam kehidupan seharihari. Pada tahap ini peserta didik dipandu membangun kepekaannya terhadap fenomena yang terjadi, dengan cara memberikan motivasi agar siswa meningkatkan kemampuan dalam mengajukan pertanyaan, melatih kemampuan dalam mengumpulkan data untuk menjawab pertanyaan, serta dipandu untuk membuat kesimpulan atas jawaban pertanyaan tersebut.

Indikator mengevaluasi dan mendesain penyelidikan ilmiah merupakan kemampuan melakukan kegiatan mendeskripsikan, menilai penyelidikan ilmiah dan dapat menjawab pertanyaan secara ilmiah. Kompetensi mengevaluasi dan mendesain penyelidikan ilmiah dibutuhkan untuk mengevaluasi laporan dari penemuan dan investigasi secara kritis [14]. Indikator ini menuntut peserta didik membuat kesimpulan dan menafsirkan bukti ilmiah. Dalam tahap pembelajaran model inkuiri bebas yang mendukung peserta didik melakukan kegiatan menyusun kesimpulan hasil pengamatan adalah pengumpulan data dalam kegiatan pengamatan. Tahap pembelajaran ini, peserta didik melakukan pengumpulan data atau literatur yang merujuk pada topik pembelajaran, setelah itu peserta didik secara berkelompok akan melakukan pengakajian dan pengamatan yang dilakukan untuk menguji rumusan masalah dan hipotesis yang telah disusun sebelumnya dengan merancang pengamatana sesuai dengan lembar kerja yang telah disediakan sebelumnya. Menerapkan kegiatan praktikum dalam pembelajaran IPA terpadu menuntun peserta didik melatih kemampuan merencanakan pembelajarannya, melaksanakan pembejaran, dan mengevaluasi pembelajaran secara mandiri [15]. Setelah itu peserta didik akan menjawab pertanyaan dan menyusun kesimpulan berdasarkan data yang telah dikumpulkan melalui kegiatan pengamatan sebelumnya. Langkah pembelajaran menyusun kesimpulan dapat mengembangkan kompetensi indikator mengevaluasi dan merancang penyelidikan ilmiah [12]. Melalui kegiatan pengamatan siswa dapat melakukan kegiatan-kegiatan yang berorientasi pada kegiatan mengamati, mencatat hasil pengamatan, pengumpulan data, dan menarik kesimpulan, sehingga peserta didik akan menemukan sendiri konsep-konsep yang harus dipahaminya. Langkah-langkah pembelajaran melalui kegiatan pengamatan akan menuju suatu kegiatan menyimpulkan yang didukung oleh data dan fakta. Dengan demikian untuk memperoleh pencapaian indikator literasi mengevaluasi dan mendesaian penyelidikan ilmiah, telah didukung dengan proses pembelajaran yang terdapat pada model inkuiri bebas. Kegiatan pembelajaran model inkuiri bebas seperti mengobservasi, meramalkan, merencanakan, dan melakukan percobaan, mengkomunikasikan dan menyimpulkan telah membangun keadaan mental peserta didik secara aktif melalui kebebasan berpikir dan fisik melalui kegiatan observasi [16].

Indikator literasi sains interpretasi data dan membuktikan data secara ilmiah merupakan kemampuan individu untuk melakukan anlisis dan mengevaluasi data, memberi tanggapan dan argumen untuk mencapai kesimpulan dengan tepat [17]. Dengan demikian, peserta didik dituntut untuk memiliki kemampuan dalam menafsirkan bukti ilmiah atau data yang diperoleh melalui kegiatan pengamatan ataupun bersarkan teori/literatur yanga ada, yang dipergunakan untuk menarik kesimpulan dan memberikan alasan yang tepat mengapa alasan tersebut dapat diterima maupun ditolak. Penerapan model pembelajaran inkuiri bebas membuat kemampuan berpikir peserta didik lebih divergen [18]. Pencapaian kemampuan literasi pada indikator Dalam tahap pembelajaran inkuiri bebas, kegiatan menganalisis untuk mencapai suatu kesimpulan berdasarkan teori dan data hasil pengamatan sebagai bukti ilmiah terdapat pada tahap formulasi penjelasan maupun analisis proses inkuiri. Secara berkelompok menganalisis data bersama kelompok yang diperkuat dengan data dan teori yang mendukung hasil pengamatan dan mengaitkan kesimpulan dengan rumusan yang telah dibuatnya. Pada tahap ini peserta didik melakukan proses pembelajaran yang mendukung untuk mengembangkan kemampuan literasi sains pada indikator ketiga yang difasilitasi dengan kegiatan anasis secara berkelompok maupun diskusi kelas. Kemampuan peserta didik menggunakan bukti ilmiah dan menjelaskan fenomena ilmiah dapat semakin berkembang melalui kegiatan diskusi kelas, dimana peserta didik akan menyampaikan pendapat secara lisan dan tulisan hasil pengamatan [19].

Berdasarkan uraian tersebut dapat disimpulkan bahwa tahap-tahap pembelajaran menggunakan model inkuiri bebas memfasilitasi peserta didik membangun dan mendukung tercapainya kemampuan literasi sains peserta didik kelas XI SMAN 2 Labuapi tahun ajaran 2019/2020. Model inkuiri bebas memiliki tahap pembelajaran yang berorientasi pada penyelidikan yang memungkinkan peserta didik melatih kemampuan literasi sains bila difasilitasi kegiatan pembelajaran yang mengarah pada stimulus kemampuan literasi sains peserta didik.

\section{KESIMPULAN}

Berdasarkan hasil dapat disimpulkan bahwa "Terdapat pengaruh model inkuiri bebas terhadap peningkatan kemampuan literasi sains siswa kelas XI SMAN 2 Labuapi, yang didukung dengan hasil uji multivariat dengan nilai $(\mathrm{p}=0,000)$. Nilai signifikasi menunjukan bahwa $(0,002<0,05)$, yang berarti $H$ 。 ditolak." 


\section{DAFTAR PUSTAKA}

[1] Taofiq, M., Setiadi, D., \& Hadiprayitno, G. (2018, June). Analisis Implementasi Model Pembelajaran Inkuiri dan Problem Based Learning Terhadap Kemampuan Literasi Sains Biologi Ditinjau Dari Kemampuan Akademik yang Berbeda di SMAN 1 Kayangan. In Prosiding Seminar Nasional Pendidikan Biologi (Vol. 1, No. 1, pp. 549-555).

[2] Nugraha, A. J., Suyitno, H., \& Susilaningsih, E. (2017). Analisis kemampuan berpikir kritis ditinjau dari keterampilan proses sains dan motivasi belajar melalui model pbl. Journal of Primary Education, 6(1), 35-43.

[3] Setiadi, D. (2014). Model Pembelajaran Berbasis Peningkatan Literasi Sains dan Implementasinya dalam Kurikulum Sains SMP 2013. Jurnal Pijar Mipa, 9(1).

[4] Retnoningsih, A. (2015). Desain Pembelajaran Literasi Sains Berbasis Problem Based Learning dalam Membentuk Keterampilan Berpikir Kritis Siswa. Journal of Innovative Science Education, 4(2).

[5] Rahayuni, G. (2016). Hubungan keterampilan berpikir kritis dan literasi sains pada pembelajaran IPA terpadu dengan model PBM dan STM. Jurnal penelitian dan Pembelajaran IPA, 2(2), 131-146.

[6] Setiadi, D. (2014). Model Pembelajaran Berbasis Peningkatan Literasi Sains dan Implementasinya dalam Kurikulum Sains SMP 2013. Jurnal Pijar Mipa, 9(1).

[7] Dewi, P. S. (2016). Perspektif Guru sebagai Implementasi Pembelajaran Inkuiri Terbuka dan Inkuiri Terbimbing terhadap Sikap Ilmiah dalam Pembelajaran Sains. Tadris: Jurnal Keguruan Dan Ilmu Tarbiyah, 1(2), 179-186.

[8] Jumini, S. (2013, June). Penggunaan Metode Open Inquiry untuk memperbaiki kualitas praktikum Elektronika Dasar. In Prosiding Seminar Nasional Sains dan Pendidikan Sains VIII, Fakultas Sains dan Matematika, $U K S W$ (Vol. 4, No. 1, pp. 121-132).

[9] Putri, N. A., \& Pantiwati, Y. P. (2015). Perbedaan model pembelajaran open inquiry dan guided inquiry berdasarkan kemandirian belajar dan berfikir tingkat tinggi pada mata pelajaran biologi kelas 11 MAN TempursariNgawi. JPBI (Jurnal Pendidikan Biologi Indonesia), 1(1).

[10]Zulfiani, Z., Yunistika, R., \& Juanengsih, N. (2017, October). Enhancing Students' HigherOrder Thinking Skills Through Guided and Free Inquiry-Based Learning. In International
Conference on Education in Muslim Society (ICEMS 2017). Atlantis Press.

[11] Sulistina, O., Dasna, I. W., \& Iskandar, S. M. (2012). Penggunaan Metode Pembelajaran Inkuiri Terbuka dan Inkuiri Terbimbing dalam Meningkatkan Hasil Belajar Kimia Siswa SMA Laboratorium Malang Kelas X. Jurnal Pendidikan dan Pembelajaran (JPP), 17(1), 82-88.

[12] Setyaningsih, A., Widodo, E., \& Widowati, A. (2018). PERBEDAAN ANTARA PENDEKATAN INKUIRI TERBIMBING DENGAN PENDEKATAN INKUIRI TERBIMBING BERMUATAN NATURE OF SCIENCE PADA PEMBELAJARAN IPA TERHADAP PENINGKATAN LITERASI SAINS PESERTA DIDIK SMP N 11 YOGYAKARTA. Pend. Ilmu Pengetahuan Alam-S1, 7(4), 203-208.

[13]Hapsari, D. D., Lisdiana, L., \& Sukaesih, S. (2016). Pengaruh pembelajaran berbasis proyek berbantuan modul daur ulang limbah pada literasi sains. Journal of Biology Education, 5(3), 302-309.

[14] Nugraheni, N. C., Paidi, P., \& Triatmanto, T. (2017). Kemampuan Literasi Sains Kelas X SMA Negeri Mata Pelajaran Biologi Berdasarkan Topografi Wilayah Gunungkidul. Pend. Biologi-S1, 6(5), 261-271.

[15] Wulandari, N. (2016). Analisis kemampuan literasi sains pada aspek pengetahuan dan kompetensi sains siswa smp pada materi kalor. Edusains, 8(1), 66-73.

[16] Erikko, D., Qurbaniah, M., \& Kurniati, T. (2018). Komparasi model pembelajaran inkuiri terbimbing dengan Inkuiri bebas terhadap keterampilan proses sains siswa pada materi hukum kekekalan massa kelas X mipa Sma negeri 1 pontianak. Ar-Razi Jurnal Ilmiah, 6(1).

[17] Winata, A., \& RW, I. S. (2018). Kemampuan Awal Literasi Sains Peserta Didik Kelas V SDN Sidorejo I Tuban Pada Materi Daur Air. JTIEE (Journal of Teaching in Elementary Education), 2(1), 58-64.

[18]DARMA, I. W., Sadia, I. W., \& Suma, K. (2014). Studi Komparatif Model Pembelajaran Inkuiri Bebas Dan Generatif Terhadap Pemahaman Konsep Fisika Dan Kreativitas Siswa. Jurnal Pendidikan dan Pembelajaran IPA Indonesia, 4(1).

[19] Asyhari, A. (2015). Profil peningkatan kemampuan literasi sains siswa melalui pembelajaran saintifik. Jurnal Ilmiah Pendidikan Fisika Al-Biruni, 4(2), 179-191. 